\title{
UPAYA PENINGKATAN KUALITAS MANAJERIAL LEMBAGA PENDIDIKAN ISLAM MELALUI TQM
}

\author{
Mulyadi \\ STAI Al Azhar, Menganti Gresik_Jl. Raya Menganti Krajan No 447 Gresik \\ Mulyadi@gmail.com
}

ABSTRACT One of the important challenges of Islamic educational institutions today is the weak managerial quality of the institution. This article will discuss Total Quality Management (TQM) in educational institutions, how to improve the quality of educational institutions that are managed. TQM is a management approach that can be applied in Islamic education institutions to be more effective in managing their educational resources. TQM is also called integrated quality management because it departs from efforts to improve quality in an integrated manner, covering quality, energy, infrastructure, management, and graduates.

Keywords: Total Quality Management, and Islamic educational institutions.

ABSTRAK Salah satu tantangan penting lembaga pendidikan Islam saat ini adalah lemahnya kualitas manajerial kelembagaannya. Artikel ini akan membahas Total Quality Management (TQM) di lembaga pendidikan, bagaimana meningkatkan mutu lembaga pendidikan yang di kelolanya. TQM merupakan suatu pendekatan manajemen yang dapat diterapkan dilembaga pendidikan Islam agar lebih efektif dalam mengelola sumber-sumber pendidikan yang dimiliki. TQM disebut juga manajemen mutu terpadu karena berangkat dari upaya peningkatan mutu secara terpadu, meliputi kualitas, ketenagaan, sarana prasarana, manajemen, dan lulusan.

Kata kunci: Total Quality Management, dan lembaga pendidikan Islam.

Program Studi Pendidikan Guru Madrasah Ibtidaiyah

STAI Al-Azhar Menganti Gresik, Indonesia

\section{Pendahuluan}

Masalah yang sering terjadi perbincangan dalam dunia pendidikan dewasa ini adalah lemahnya pengelolaan lembaga pendidikan yang mencakup semua komponen system pendidikan. Masalah ini sering disinggung, (Tilaar, 1992) dalam bukunya yang berjudul Management Pendidikan Nasional. Lemahnya pengelolaan lembaga pendidikan Islam terletak pada dana yang meliputi sumber pendanaan, pengelolaan keuangan, dan transportasi. Permasalahan tersebut terjadi karena belum adanya sumber daya yang kompeten di bidangnya. Dari sisi manajemen kelemahan itu bisa timbul pada tenaga pendidikan, sarana dan prasarana pendidikan, masalah yang berhubungan dengan lulusan yang akhirnya bermuara pada rendahnya kualitas pendidikan. Di sisi lain, permasalahan yang dihadapi lembaga pendidikan adalah tarik menarik kebijakan sentralisasi dan desentralisasi beserta implikasinya. Pendidikan nasional dengan system desentralisasi di Indonesia dewasa ini, pada gilirannya melahirkan permasalahan antara wewenang pemerintah pusat dan pemerintah 
daerah, sehingga masing-masing tidak berperan secara maksimal dalam menangani pendidikan. Oleh karena itu diperlukan kebijakan yang khusus agar permasalahan tersebut dapat tertangani. Manajemen pendidikan dirumuskan sebagai mobilisator segala sumber daya pendidikan untuk mencapai tujuan yang direncanakan. Oleh karena itu yang dihadapi ialah berbagai hambatan yang menghadang pencapaian tujuan tersebut.

Meningkatkan kualitas pendidikan merupakan upaya terus menerus dalam setiap lembaga pendidikan. Karena dengan upaya itulah pendidikan akan menjadi pusat pengembangan SDM yang professional di tengah-tengah masyarakat. Masalah kualitas pendidikan nasional sekarang ini masih menjadi pusat perhatian semua pihak yang demikian, hingga Wardiman menerapkan kebijaksanaan yaitu system pendidikan Link dan match. Tujuan untuk menghasilkan lulusan yang siap pakai dengan spesialisasi bidang keilmuan yang dimilikinya. Namun beberapa jauh ke bijaksanaan tersebut akan merombak system manajemen pendidikan yang sudah ada, dalam arti mengupayakan manajemen kondusif untuk tercapainya efektifitas dan efisiensi proses pelaksanaan belajar mengajar di setiap lembaga pendidikan.

Pada kenyataannya masih banyak lembaga pendidikan yang tidak mampu menciptakan manajemen yang kondusif bagi peningkatan kualitas pendidikan. Kebijakan yang diterapkan hanya menyentuh bagian luar dari pelaksanaan pendidikan itu sendiri dan belum menyentuh pelaksanaan mendasar yang banyak terjadi pada lembaga pendidikan di Indonesia masih terjadi masalah nasional, terlebih pelaksanaan pendidikan yang baru menerapkan desentralisasi dan masih banyak masalah yang memerlukan pembenahan. Dengan demikian merombak system manajemen pendidikan nasional secara menyeluruh. Hal itu bisa terwujud bila ada political will pemerintah pusat ataupun daerah untuk menitik beratkan pada manajemen pendidikan.

Upaya untuk menciptakan kondisi yang kondusif dalam mencapai tujuan pendidikan adalah mutlak membutuhkan budaya manajemen kualitas. Dengan manajemen tersebut efektifitas sekolah akan dapat terwujud secara lebih sempurna. Itulah yang dimaksud dengan Total Quality Management (TQM), yang harus diterapkan di lembaga-lembaga pendidikan dewasa ini. Karena saat ini lembaga pendidikan sedang berpacu dengan perubahan yang selalu menuntut kualitas, sehingga pendidikan harus memperhatikan dan menerapkan hal tersebut dalam pengelolaan. Sumber-sumber pendidikan secara maksimal. Bahkan masyarakat terpacu menguasai kompetensi yang tinggi di era globalisasi ini. Masyarakat 
sudah memahami dan mendapatkan informasi tentang lembaga yang out putnya berkualitas dan lembaga pendidikan out putnya tidak berkualitas.

Salah satu tantangan lembaga pendidikan yang bergerak di bidang pembangunan sumber daya manusia adalah bagaimana lembaga itu bisa mengantisipasi masyarakat yang mempunyai orientasi penilaian pada sisi mutu. Lembaga pendidikan dituntut untuk mengembangkan dan meningkatkan kualitas secara terus menerus. Meningkatkan kualitas ketenagaan, meningkatkan pelayanan terhadap siswa dan masyarakat, dan menjalin hubungan yang baik dengan lembaga-lembaga yeng berkepentingaan secara langsung maupun tidak langsung dengan pendidikan baik swasta maupun negeri. Mengelola lembaga pendidikan secara keseluruhan adalah suatu upaya memberdayakan (empowerment) sumber-sumber pendidikan dengan penerapan system manajemen mutu terpadu (Total Quality Management). TQM bila diterapkan secara maksimal akan dapat mengatasi masalah-masalah manajerial yang sering muncul di pendidikan Islam.

\section{A. Memahami Konsep Total Quality Management (TQM)}

Sebelum memahami knsep TQM terlebih dahulu perlu diketahui apa pengertian quality (mutu). Sampai sekarang ini, pengertian yang diberikan oleh para ahli manajemen, sangat beragam. Bahkan tidak jarang pemahaman tentang mutu yang dikemukakan oleh satu industri mengalami perkembangan terus-menerus. Mutu selalu terkait dengan produksi barang dan jasa dalam jangka waktu tertentu.

Revolusi mutu yang terjadi di dunia bisnis barang dan jasa dewasa ini, pada prinsipnya mengingionkan agar perusahaan mempunyai produk dan jasa bermutu, prestasi yang memuaskan dan harga terjangkau. Dengan kata lain, mutu adalah perasaan menghargai sesuatu yang baik daripada yang lain. The American Society For Quality Control seperti dikutip Jay haizer (1996) menekankan karakter dan sifat-sifat produk dan jasa yang dapat memenuhi ke butuhankebutuhan sta ndar yang berlaku, dan menekankan pada segala keistimewaan dan keunggulan yang memberikan kepuasan total pada konsumen meliputi kualitas harga produk, ketepatan waktu, pelayanan, dan pertimbangan moral, (Tilaar, 1992). Sungguhpun terjadi perbedaan dan keragaman pengertian dalam bidang mutu di dunia bisnis, ada kesamaan arah dan orientasi dalam upaya meningkatkan mutu yaitu sebagai upaya memuaskan pelanggan. Untuk itu apa yang dikemukakan tentang mutu tergantung pada konteks, persepsi, kebutuhan dan kemauan pelanggan. Selanjutnya. Deming menyebutkan syarat-syarat sesuatu yang bermutu sebagai berikut:

1. Pemimpin tidak hanya berkewajiban untuk menentukan kebutuhan customer sekarang saja, tetapi harus juga mengantisipasi kebutuhan-kebutuhan di masa mendatang. 
2. Mutu ditentukan oleh customer dan mereka terbagi dalam external customer, yaitu pemakai akhir dari produk atau jasa yang berasal dari luar organisasi, dan internal customer, yaitu mereka dalam or ganisasi yang menggunakan produk dan jasa dengan tujuan untuk pemprosesan lebih lanjut.

3. Perlu dikembangkan ukuran-ukuran untuk menilai efektifitas upaya guna memenuhi kebutuhan customer.

4. Kebutuhan dan kemauan customer harus diperhitungkan dalam desain produk dan jasa.

5. Kepuasan customer merupakan syarat yang perlu bagi mutu dan selalu menjadi tujuan proses untuk menghasilkan produk dan jasa.

6. Mutu juga harus dapat menentukan harga produk dan jasa, (Robbin, 1983).

Dari sekian pembahasan tentang mutu, yang pernah dilakukan oleh para ahli ekonomi, maka bisa dipahami bahwa mutu dalam dunia bisnis selalu mengacu pada pengelolaan produk dan jasa untuk memenuhi kebutuhan pelanggan secara memuaskan.

Berikut ini akan dikaji TQM sebagai suatu teori manajemen. Teori tersebut di terapkan pertama kali oleh Deming pada tahun 1984 untuk menghadapi situasi perekonomian yang se dang bergejolak setelah perang dunia ke II. Kemudian teori tersebut di kembangkan oleh ahli manjemen. Dari berbagai kajian tentang TQM dapat dipastikan bahwa pendekatan yang digunakan yaitu pendekatan system organisasi. Pendekatan organisasi dipandang sebagai satukesatuan yang saling mendukung secara fungsional. Untuk itulah perhatian terhadap kualitas harus mendapat bagian dari tanggung jawab semua yang terlibat langsung dalam menghasilkan produk dan jasa termasuk pelanggan harus dilibatkan dalam proses tersebut. Karena TQM merupakan system, maka ada beberapa hal yang harus diperhatikan dan dikembangkan dalam organisasi yaitu:

a. System budaya, yakni serangkaian fungsi atau aktifitas didalam sebuah organisasi yang bekerjasama untuk tujuan organisasi tersebut.

b. System teknik, yang terdiri dari factor-faktor seperti teknologi yang dipergunakan dan infrastrukrtur fisik (termasuk perangkat lunak dan konfigurasi perangkat keras, serta investasi modal yang dibutuhkan untuk mencapai misi perusahaan.

c. System manajemen, yang ditekankan pada efektifitas berbagai proses yang dipakai oleh sebuah organisasi dalam mengelola asset yang dimiliki manusia.

\section{B. Implementasi TQM di Lembaga Pendidikan Islam}

Topik tentang kualitas pendidikan sekarang ini dan masa-masa mendatang akan terus semakin menarik, karena output pendidikan akan menjadi bagian terpenting ketika ter jadi kompetisi yang semakin tinggi antara lembaga-lembaga pendidikan yang ada. Masyarakat 

sebagai customer lembaga pendidikan akan menilai lembaga pendidikan dengan criteria kualitas atau mutu secara menyeluruh, meliputi status, manajemen pelaksanaan, disiplin keilmuan, proses pengajaran dan pembelajaran keterampilan dan perilaku. Kecenderungan masyarakat dalam menilai pendidikan dengan penekanan kualitas tersebut harus mendapatkan perhatian para praktisi kependidikan. Itu dimaksudkan agar lembaga pendidikan islam tetap eksis dengan orientasi untuk mencetak kualitas output yang bermutu dan relevan dengan kebutuhan masyarakat. Masalah tersebut terkait erat dengan bagaimana mengelola lembaga pendidikan islam secara professional.dalam hal ini sekolah dipandang sebagai suatu system organisasi yang komponen-komponennya terkai secara fungsional dalam mencapai tujuan. Seperti yang pernah diungkapkan bagian terdahulu, TQM banyak dikembangkan dalam organisasi manufaktur di dunia ekonomi. Memang perancangan TQM pertama kali dikemukakan untuk meningkatkan produktifitas organisasi manufaktur. Akan tetapi tidak tertutup kemungkinan TQM diterapkan dalam dunia pendidikan. TQM sebagai suatu pendekatan dalam mengelola organisasi pendidikan dimaksudkan untuk mengarahkan segala sumber pendidikan dengan titik tekan pada kualitas secara menyeluruh dalam rangka mencapai tujuan.

Dalam menerapkan TQM pada dunia pendidikan Islam, maka seorang kepala sekolah dituntut membangun efektifitas dan efisiensi dalam pendayagunaan sumber-sumber pendidikan Seorang pimpinan harus terus-menerus melakuakan perubahan dan perbaikan kualitas dan berpijak pada kebutuhan masyarakat yang menjadi customer dan consumer pendidikan. Organisasi sekolah menempati posisi penting dalam rangka meningkatkan efektifitas dan kualitas manajemen sekolah. Hal karena kualitas proses belajar-mengajar ditentukan oleh tiga factor yaitu: guru, kualitas siswa dan kualitas manajemen. Untuk itu upaya meningkatkan kualitas dan relevansi pendidikan islam yang didukung oleh manajemen yang baik, harus tetap menjadi perhatian utama pemerintah dan masyarakat, (Robbin: 90).

Menarik untuk dikaji dalam tulisan ini adalah upaya untuk menerapkan TQM dalam dunia pendidikan Islam dalam rangka mengelola sumber-sumber pendidkan. Upaya ini dilakukan dengan cara mengembangkan mutu (quality) dalam sistem organisasi madrasah. Untuk meningkatkan manajemen lembaga pendidikan Islam secara personal perlu diterapkan upaya peningkatan mutu secara terpadu yang mungkin juga disebut manajemen terpadu. Menekankan mutu terpadu ini meliputi peningkatan kualitas ketenagaan, sarana prasarana, manajemen dan kelulusan. Dalam penjelasan diatas jelas bahwa mengelola organisasi lembaga pendidikan Islam memerlukan pendekatan manajemen ilmiah dalam rangka mendayagunakan sumber-sumber secara profesional. Dalam rangka itulah TQM akan membe rikan pemahaman baru tentang madrasah sebagai organisasi yang dinamis dengan selalu melakukan peru bahan konstruktif dan positif. Upaya ini dilakukan dengan cara menggerakkan hal-hal sebagai berikut.

1. Mengoptimalkan Peranan Kepemimpinan 
Dalam organisasi madrasah seorang kepala madrasah hendaknya mampu menggerakkan segala komponen untuk mencapai tujuan pendidikan, dalam arti setiap komponen yang terkait dengan upaya terwujudnya upaya tersebut. Seorang kepala madrasah dituntut mengembangkan pola kepemimpinan demikratis, serta dapat memberikan contoh yang relevan. Misalnya penggunaan alat, bahasa, dan data secara tepat. Ketika TQM digunakan sebagai kunci proses manajemen, kepala madrasah berperan sebagai penasehat sekaligus motor penggerak dalam upaya perbaikan. Artinya kepala madrasah harus memahami tujuan, prinsip, dan elemen-elemen pendukung TQM dan mampu mengelola secara terus menerus dalam rangka mencapai peningkatan kualitas madrasah yang diharapkan. Seorang kepala madrasah harus mampu merumuskan dan mensosialisasikan misi dan visi madrasah pada seluruh staf, mengembangkan filsafat mutu dalam mencapai tujuan yang telah ditetapkan. Konsep tentang kualitas pendidikan harus benar-benar dipahami oleh komponen madrasah yang terlibat secara langsung atau tidak langsung. Dalam hal ini kepala mempunyai peran yang penting.

2. Perubahan Budaya

Upaya untuk merubah budaya pada mulanya sulit untuk dilakukan karena upaya ini membutuhkan perubahan sikap dari setiap staf madrasah, dan metode kerja yang berbeda-beda. Berkaitan dengan upaya mengadakan perubahan budaya alam TQM ada tiga langkah yang harus diperhatikan, yaitu: freezing, moving, and refrezing (Harson, 1995). Artinya, jika kepala madrasah hendak mengadakan perubahan budaya (kualitas) dalam organisasi madrasah yang harus di lakukan adalah melelehkan status quo, kemudian menggerakkan ke arah yang baru (budaya baru). Jika sudah mantap maka langkah berikutnya adalah membakukan. Namun demikian, walau sudah dibakukan, pada saat nanti dapat terjadi perubahan.

3. Memfokuskan Kebutuhan Masyarakat Tentang Mutu Pendidikan

(Tony Tawsand), menjelaskan posisi strategis kebutuhan masyarakat dalam menentukan orientasi dan tujuan pendidikan (Robbin: 83). Masyarakat yang terdiri dari customer dan cunsomer pendidikan merupakan pengguna jasa pendidikan yang secara tidak langsung akan menentukan estabilishment lembaga tersebut. Misi utama TQM di lembaga pendidikan adalah memenuhi kebutuhan masyarakat. Lembaga pendidikanIslam yang unggul akan selalu menjagakedekatan dengan masyarakat serta memiliki obsesi terhadap kualitas. Kepala madrasah harus dapat mengembangkan paradigma baru yang dapat memprioritaskan kepuasan masyarakat. Dalam TMQ, masyarakat yang akhirnya menentukan kualitas. 
4. Memfokuskan Perhatian Pada Proses untuk Mewujudkan Tujuan Organisasi Pendidikan

Dengan memusatkan perhatian pada proses belajar mengajar maka setiap komponen pendidikan harus memberikan kontribusi secara maksimal. Segenap anggote madrasah harus memiliki sense belonging dan sense of responsibility, dan mengetahui fungsi masing-masing dalam upaya pencapaian tujuan yang telah ditetapkan. Memusatkan perhatian pada proses maka hal-hal yang mendukung kelancaran proses belajar mengajar seperti sarana dan praswarana sekolahharus diupayakan dengan maksimal. Kunci keberhasilan budaya TQM adalah suatu hubungan yang efektif baik secara internal maupun eksternal antara customer dan supplier. Semua jaringan dan media komunikasi baik secara vertikal maupun horizontal perlu dioptimalkan. Hal ini sangat diperlukan untuk membentuk iklim yang kondusif dan terciptanya budaya komunikasi dengan memanfaatkan semua media secara harmonis untuk lebih mengimplementasikan TQM di lembaga pendidikan Islam.

5. Melakukan Inovasi Terus Menerus Terhadap Mutu Pendidikan

Yang dimaksudkan dengan mutu pendidikan ialah upaya untuk meningkatkan fungsi sumber-sumber pendidikan. Melakukan perbaikan mutu secara terus menerus akan menjadikan madrasah proaktif terhadap perubahan yang terjadi ditengah masyarakat. Itu yang disebut resposibilities sparties, (Tawsand, 1983) yaitu guru, orang tua, administrator dan komunitas masyarakat semuanya bertanggung jawab. TQM merupakan suatu pendekatan dalam upaya mencari bentuk baku dalam lembaga pendidikan Islam sehingga fokus bukan hanya diarahkan pada kebijaksanaan peningkatan kualitas jangka pendek melainkan kualitas jangka panjang. Inovasi, peningkatan dan perubahan merupakan inti TQM. Guru administrator, orang tua dan komunitas masyarakat harus menganalisis apa apa yang telah dikerjakan di madrasah dan merencanakan untuk meningkatkannya. Untuk meningkatkan budaya peningkatan budaya peningkatan yang berkelanjutan para pimpinan lembaga pendidikan Islam harus percaya kepada kemampuan staf sehingga mau mendelegasikan keputusan pada tingkat yang sesuai. Hal tersebut dapat meningkatkan tanggung jawab staf dalam rangka memberikan kualitas dan tuntutan kerja. Staf madrasah memerlukan kebebasan untuk bekerja dalam suatu kerangka kerja yang jelas mencapai tujuan. Peningkatan yang dilaukan demi tahap secara berkelanjuatan menjadi fokus sekaligus syarat yang utama dalam mengimplementasikan TQM di lembaga pendidikan Islam.

6. Profesionalisme dan Fokus Pelanggan 
Memersatukan unsur terbaik dari profesisonalisme dengan TQM merupakan model penting mencapai tujuan lembaga pendidikan Islam. Fokus keprofesionalan itu adalah untuk memenuhi keinginan dan kepuasan pelanggan (murid, orang tua murid dan masyarakat) dalam jangka panjang dengan implikasi opini pelanggan terhadap sistem layanan jasa pendidikan di madrasah menjadi terbentuk dengan baik.

7. Kolega Sebagai Pelanggan

Fokus TQM salam lembaga pendidikan Islam bukan sekedar memenuhi pelanggan dari luar, akan tetapikolega-kolega yang ada di dalam lembaga pendidikan Islam juga sebagai penggan. Keseimbangan dalam memenuhi semua pelanggan internal maupun eksternal di lakukan secara proporsional.

8. Kualitas Belajar

Implimentasi TQM di lembaga pendidikan Islam diperlukan arah kualitas sistem layanan pengalaman belajar. Peserta didik memiliki karakteristik yang berbeda-beda dan kecenderungan mereka. Oleh karena itu madrasah yang menerapkan TQM sebaiknya mengantisipasi sistem belajar secara serius, sehingga mendapatkan atrategi yang baik untuk melayani masing-masing individu yang mempunyai perbedaan belajar. Prinsip TQM diperlukan kesepakatan dalam menetapkan misi. Dalam proses pembentukan kesepakatan bersama diperlukan ketetapan tentang kualitas dari forum agar diberikan umpan balik serta memberikan kesempatan kepada anak didik untuk mengatur cara belajar sendiri. Selain itu wakil dari orang tua diperlukan untuk mengantisipasi kesalahan dan mencari jalan keluar.

9. Pemasaran Internal

Pemasaran internal adalah alat untuk mengomunikasikan berbagai informasi kepada staf guna meyakinkan tentang apa yang terjadi dimadrasah sehingga staf memiliki kesempatan untuk memberi umpan balik. Hal ini didasarkan pada asumsi bahwa staf tidak akan menyampaikan ide pada lembaga jika staf tidak memiliki perhatian pada tujuan lembaga. Pemasaran internal adalah bentuk pola madrasah mengomunikasikan ide. Jika pemasaran internal berjalan dengan baik, maka dukunagn terhadap implementasi TQM dalam bidang pendidikan dapat berjalan dengan baik yang pada akhirnya akan mendongkrak pada pemasaran eksternal yang lebih luas.

\section{Simpulan}

TQM adalah suatu pendekatan yang ditujukan untuk menungkatkan kualitas lembaga pendidikan secara terus menerus dengan memfokuskan kebutuhan masyarakat, perbaikan pada proses, keterlibatan anggota dalam menjaga eksistensinya. TQM adalah suatu pendekatan dalam mengelola 
organisasi dengan melihat organisasi dalam sistem budaya, sistem tehnik dan sistem manajemen. Dari uraian di atas dapat disimpulkan, manajemen lembaga pendidikan islam adalah suatu upaya untuk meningkatkan kualitas pendayagunaan sumber-sumber pendidikan Islam dalam rangka menciptakan efisiensi dan efektifitas demi tercapainya kualitas lulu san yang baik dan relevan dengan kebutuhan masyarakat, dalam mengelola organisasi dan lembaga pendidikan is lam dengan sistem TQM maka organisasi pendidikan dilihat sebagai suatu sistem yang mengutamakan optimilisasi peranan kepemimpinan, perubahan budaya, memfokuskan kebutuhan masyarakat tentang mutu pendidikan, memfokuskan per hatian pada proses untuk mewujudkan tujuan organisasi pendidikan, melakukan inovasi terus menerus terhadap mutu pendidikan, meningkatkan profesionalisme dan memfokuskan pelanggan, menjadikan kolega sebagai pelanggan, meningkatkan kualitas belajar dan mamasarkan ide secara inter nal, lembaga pendidikan Islam harus dibangun secara profesional sebagaimana layaknya organisasi profesional lainnya dengan tujuan untuk melakukan investasi sumberdaya manusia.

\section{Daftar Pustaka}

Abrasi, Al. M. A. (tt). At Tar biyah al Islamiyah. Mesir: Isa al Bab al Halabi wa Shirkah.

Bukori. 1989. Pendidikan Islam di Indonesia, Problem Masa Kini dan Perspektif Masa Depan, Dalam Islam Indonesia Menatap Masa Depan. Jakarta: P3M.

Harson, E. Mark. 1995. Education Administration and Organization Behavior. University of California.

Stephen. P, Robbin. 1993. Essential of Organizational Behavior. New Jersey: Englewood Cliffs. Prentic.

Tawsand, Tony. 1994. Effectif Schooling for the Community. Canada: Routlange.

Tilaar, H.R. 1992. Manajemen Pendidikan Nasional. Bandung: PT Rosda Karya. Zuhairini. 1995. Filsafat P endidikan Islam. Jakarta: Bumi Aksara. 